\title{
Influence of antimicrobial solutions in the decontamination and adhesion of glass-fiber posts to root canals
}

\author{
Gisele Aihara HARAGUSHIKU ${ }^{1}$, Eduardo Donato Eing Engelke BACK ${ }^{2}$, Paulo Henrique TOMAZINHO², Flares BARATTO \\ FILHO², Adilson Yoshio FURUSE ${ }^{3}$
}

\author{
1- Private practice, Bauru, SP, Brazil \\ 2- Graduate Program in Dentistry, Positivo University, Curitiba, PR, Brazil \\ 3- Department of Operative Dentistry, Endodontics and Dental Materials, Bauru School of Dentistry, University of São Paulo, Bauru, SP, Brazil.
}

Corresponding address: Adilson Yoshio Furuse - Departamento de Dentística, Endodontia e Materiais Odontológicos, Faculdade de Odontologia de Bauru, Universidade de São Paulo - Alameda Dr. Octávio Pinheiro Brisolla, 9-75 - Bauru - SP - Brazil - 17012-901 - Phone: +55 $143235-8323$ - Fax: +55 143235 8523 - e-mail: furuse@usp.br

Submitted: January 7, 2015 - Modification: June 2, 2015 - Accepted: July 10, 2015

\section{ABSTRACT}

bjective: This study evaluated the effect of root canal disinfectants on the elimination of bacteria from the root canals, as well as their effect on glass-fiber posts bond strength. Material and Methods: Fifty-three endodontically treated root canals had post spaces of $11 \mathrm{~mm}$ in length prepared and contaminated with E. faecalis. For CFU/ml analysis, eight teeth were contaminated for 1 h or 30 days $(n=4)$. Teeth were decontaminated with $5 \%$ $\mathrm{NaOCl}, 2 \% \mathrm{CHX}$, or distilled water. As control, no decontamination was conducted. After decontamination, sterile paper points were used to collect samples, and CFU/ml were counted. For push-out, three groups were evaluated $(n=15)$ : irrigation with $2.5 \% \mathrm{NaOCl}$, $2 \% \mathrm{CHX}$, or sterile distilled water. A bonding agent was applied to root canal dentin, and a glass-fiber post was cemented with a dual-cured cement. After 24 h, 1-mm-thick slices of the middle portion of root canals were obtained and submitted to the push-out evaluation. Three specimens of each group were evaluated in scanning electron microscopy (SEM). Data were analyzed with one-way ANOVA and Dunnett's T3 test $(\alpha=0.05)$. Results: The number of $\mathrm{CFU} / \mathrm{ml}$ increased from $1 \mathrm{~h}$ to 30 days of contamination in control and sterile distilled water groups. Decontamination with $\mathrm{NaOCl}$ was effective only when teeth were contaminated for $1 \mathrm{~h}$. $\mathrm{CHX}$ was effective at both contamination times. $\mathrm{NaOCl}$ did not influence the bond strength $(p>0.05)$. Higher values were observed with $\mathrm{CHX}(\mathrm{p}<0.05)$. SEM showed formation of resin tags in all groups. Conclusion: $\mathrm{CHX}$ showed better results for the irrigation of contaminated root canals both in reducing the bacterial contamination and in improving the glass-fiber post bonding.

Keywords: Shear strength. Post and core technique. Sodium hypochlorite. Chlorhexidine.

\section{INTRODUCTION}

Endodontically treated teeth with great coronal destruction generally need glass-fiber posts for better retention of crowns or resin composite restorations. Although there is evidence to support the idea that endodontically treated teeth are not reinforced by posts ${ }^{21}$, it is recognized that fiber posts better distribute the stress generated on teeth under function ${ }^{22}$. On the other hand, most failures involving the reconstruction of these teeth are due to bond strength failure in luting the post with resin-based cements $^{20}$. The luting relies on the formation of a hybrid layer into dentin, which depends on the treatment of dentinal surface, the flow of the resin cement into the root canal, as well as the interaction between the adhesive material and intertubular dentin ${ }^{9}$. However, the treatment of the post space is an aspect that is normally overlooked when considering an oral infected environment and the exposure of dentin to saliva.

The contamination of the root canal system with saliva has been identified as a potential cause of endodontic failure, especially when the guttapercha is removed from the coronal and middle thirds, leaving only a remnant of 3-5 mm $\mathrm{mm}^{10,17}$. For 
this reason, root canal cleanliness before adhesive luting is an indispensable step for preventing leakage and endodontic treatment failure. Sodium hypochlorite $(\mathrm{NaOCl})$ and chlorhexidine $(\mathrm{CHX})$ are widely used with the aim of biofilm removal ${ }^{5}$, solvency of organic tissues, and neutralization of toxic products ${ }^{30}$. However, the long exposure to $\mathrm{NaOCl}$ could negatively affect adhesive techniques due to the superficial oxidation effects on the polymerization of resin monomers, decreasing the bond strength ${ }^{4}$. Some concerns regarding the influence of irrigating solutions on the bond strength of endodontic sealers, as well as of materials used to repair furcation perforations, have been raised ${ }^{11,19}$. However, the effect of these solutions when there is contamination of the post space before the luting of fiber-reinforced posts still needs to be addressed.

The aim of this study was to evaluate the influence of these solutions on bond strength of cemented glass-fiber posts, including bonding failures. The formation of resin tags into the dentinal tubules, and the effectiveness of $\mathrm{NaOCl}$ and $\mathrm{CHX}$ to decontaminate root canals exposed to Enterococcus faecalis were also evaluated. The null hypotheses were: there would be no influence of the irrigating solutions on the shear bond strength of glass-fiber posts luted to contaminated root canals; and there would be no difference between the solutions employed to decontaminate root canals.

\section{MATERIAL AND METHODS}

\section{Root canal preparation and post space preparation}

Fifty-three sound human maxillary canines had their crowns sectioned to obtain roots of $16 \mathrm{~mm}$ in length. Teeth were sterilized in a steam autoclave at $121^{\circ} \mathrm{C}$ for $20 \mathrm{~min}$ and then maintained in $0.9 \%$ sterile saline solution at $9^{\circ} \mathrm{C}$. The Research Ethics Committee of Positivo University, Curitiba, PR, Brazil approved this study under the protocol \#77947.

The working length was established at 15 $\mathrm{mm}$ and final diameter at $0.60 \mathrm{~mm}$. A ProFile.04 rotary system (Dentsply Maillefer, Balaigues, Switzerland) for the crown-down technique was used with an electric motor (X Smart, Dentsply Maillefer, Balaigues, Switzerland) at $250 \mathrm{rpm}$ and torque of $1.5 \mathrm{~N}$. The specimens were filled with lateral condensation employing \#60 gutta-percha points (Dentsply Maillefer, Petrópolis, RJ, Brazil), accessory MF cones (Dentsply Maillefer, Petrópolis, RJ, Brazil), and AH Plus sealer (Dentsply DeTrey, Konstanz, Germany).

Post spaces were prepared by removing the filling material with \#3 and \#4 Largo drills
(Dentsply-Maillefer, Petrópolis, RJ, Brazil), at an 11-mm-length, leaving $4 \mathrm{~mm}$ of apical seal. The preparation was completed with the specific drill for the glass-fiber post (WhitePost DC2, FGM, Joinville, SC, Brazil).

For the evaluation of the shear bond strength, forty-five teeth were contaminated for $1 \mathrm{~h}$ with Enterococcus faecalis (ATCC 19433). Before contamination, teeth's external surfaces were protected with nail polish varnish (Colorama, Maybelline, New York, NY, USA).

$E$. faecalis were cultivated in $5 \mathrm{ml}$ of sterilized brain-heart infusion (BHI) broth and incubated for $24 \mathrm{~h}$ at $37^{\circ} \mathrm{C}$ in suitable respiratory conditions. The test tubes containing the BHI broth with the cultivated bacteria were adjusted to the 0.5 tube of the McFarland scale at a concentration of approximately $1.5 \times 10^{8}$ cells $/ \mathrm{ml}$ with the aid of the same diluent. Each tooth was individually placed in a sterile $1.5 \mathrm{ml}$ Eppendorf tube filled with bacterial inoculum of $E$. faecalis. To ensure proper contact to the root canal walls, the inoculum was firstly injected with a 20-ml-sterile-syringe (BD, São Paulo, SP, Brazil) and a 17-mm 30-gauge cannula (NaviTip, Ultradent, South Jordan, UT, USA). Samples were incubated at $37^{\circ} \mathrm{C}$ for $1 \mathrm{~h}$.

The contaminated specimens were divided into three groups $(n=15)$ : G-I - distilled water (control), G-II - 2.5\% NaOCl, and G-III - 2\% CHX (Clorhexidina S, FGM, Joinville, SC, Brazil). Each specimen had its canal irrigated with $10 \mathrm{ml}$ of each solution for approximately $1 \mathrm{~min}$. Glass-fiber posts (WhitePost DC2, FGM, Joinville, SC, Brazil) were cemented with a dual-cured resin-based cement (AllCem, FGM, Joinville, SC, Brazil) following the manufacturer's recommendations: 15-s-etching with $37 \%$ phosphoric acid, 20-s-washing with sterile water and a syringe, and drying with paper cones. A two-step etch-and-rinse adhesive (Ambar, FGM, Joinville, SC, Brazil) was applied using a long applicator tip, followed by 15 -s-air-drying and 20-s-light-curing with an LED device (LD Max, Gnatus, São Paulo, SP, Brazil; $400 \mathrm{~mW} / \mathrm{cm}^{2} ; 470$ $\mathrm{nm}$ ). The silane (Prosil, FGM, Joinville, SC, Brazil) was applied at the glass-fiber post followed by the application of the same adhesive. The resin cement was inserted into the canal with an auto-mixture tip. The glass-fiber post was placed in position and the cement was light-cured for $40 \mathrm{~s}$. Samples were stored in distilled water at $37^{\circ} \mathrm{C}$ for $24 \mathrm{~h}$.

Roots were then transversely sectioned into 1-mm-thick slices (Isomet 1000 South Bay Technology, San Clemente, CA, USA) after removing the first $4 \mathrm{~mm}$ of the coronal region. One slice corresponding to the middle third of the root canal per tooth was subjected to the push-out evaluation on a testing machine (Emic DL 2000, São José dos Pinhais, PR, Brazil) by applying a 
compression load through a cylindrical tip of 0.6 $\mathrm{mm}$ diameter at $0.5 \mathrm{~mm} / \mathrm{min}$. Data were obtained in MPa and statistically analyzed by one-way ANOVA and Dunnett's T3 test $(\alpha=0.05)$.

The fracture displacement area was analyzed with a photomicroscope (SZX9 Olympus Optical Microscope, Tokyo, Japan) with $16 \times$ magnification. Failures were classified as adhesive (cement detachment of the tooth), cohesive (fracture between post and cement), or mixed (adhesive and cohesive failure in the same specimen).

Three specimens of each group were randomly chosen for scanning electron microscopy (SEM) analysis at $500 \times$ and $3000 \times$ magnification. The qualitative analysis included the observation of the formation of tags into the dentinal tubules.

To compare the antimicrobial effectiveness of the irrigation procedures, eight teeth were contaminated with Enterococcus faecalis (ATCC 19433) for two different periods: $1 \mathrm{~h}(\mathrm{n}=4)$ or 30 days $(n=4)$. Teeth were decontaminated with $2.5 \%$ $\mathrm{NaOCl}, 2 \% \mathrm{CHX}$ (Clorhexidina S, FGM, Joinville, SC, Brazil), or sterile distilled water. As control, no decontamination was conducted in one tooth per period. Samples were incubated at $37^{\circ} \mathrm{C}$ for $1 \mathrm{~h}$ or 30 days. Every two days, $0.3 \mathrm{ml}$ was removed from each Eppendorf and replaced with $0.3 \mathrm{ml}$ of sterile BHI broth to maintain viable bacteria.

After contamination, microbial samples were collected from root canals. Three \#60 sterile paper points (Dentsply Maillefer, Petrópolis, RJ, Brazil) were used to collect samples from each tooth. Microbial samples were then placed in test tubes containing sterile $\mathrm{BHI}$ for the colony forming units (CFU) counting per inoculation on agar plate.

The decontamination was conducted with a sterile 20-ml-syringe and a 17-mm 30-gauge cannula (NaviTip, Ultradent, South Jordan, UT, USA). Each tooth had its root canal irrigated for 1 min with $10 \mathrm{ml}$ of the evaluated solution in movements of insertion and removal to create a flux inside the root canal. The roots were finally irrigated with $10 \mathrm{ml}$ of sterile distilled water.

After decontamination, microbial samples were collected and placed in test tubes containing sterile $\mathrm{BHI}$, agitated in Vortex, and incubated at $35^{\circ} \mathrm{C}$ for
$24 \mathrm{~h} . \mathrm{CFU} / \mathrm{ml}$ were counted through a spread plate technique in which the microbial BHI broth was successively diluted until $10^{-7}$. The count of CFU/ml was conducted after incubation for $48 \mathrm{~h}$ at $37^{\circ} \mathrm{C}$.

\section{RESULTS}

Mean values and standard deviations of shear bond strength are shown in Table 1 . There were significant differences between the effect of $\mathrm{NaOCl}$, $\mathrm{CHX}$, and water $(p=0.001)$. The highest bond strength values were observed when $\mathrm{CHX}$ was used as the decontamination solution $(p<0.05)$.

For all groups the majority of failures were mixed, occurring between the resin-cement and the dental structure (Table 1). All groups showed formation of resin tags in the dentinal tubules (Figure 1).

The number of CFU/ml increased from $1 \mathrm{~h}$ to 30 days of contamination in both control (without decontamination) and sterile distilled water groups. The use of sterile distilled water increased the number of CFU/ml. The decontamination with $\mathrm{NaOCl}$ was effective only when the contamination occurred for $1 \mathrm{~h}$, while $\mathrm{CHX}$ was effective at both contamination times (Figure 2).

\section{DISCUSSION}

The null hypotheses evaluated were rejected, since the irrigation with $\mathrm{CHX}$ resulted in higher bond-strength and there were differences between the solutions employed. No statistical difference in the bond-strength between the irrigation with sterile distilled water and the decontamination with $\mathrm{NaOCl}$ was observed. It is known that the ionization of $\mathrm{NaOCl}$ generates sodium chloride and oxygen, which causes inhibition of interfacial polymerization of dental adhesives ${ }^{4}$. Moreover, residual reactive free radicals in dentin treated with $\mathrm{NaOCl}$ may compete with free radicals generated during the activation of light-cured adhesives, resulting in premature chain termination and incomplete curing 6,12,28. The idea that $\mathrm{NaOCl}$ could reduce the bond-strength of the glass-fiber post to the root canal was not confirmed by this study,

Table 1- Mean values (in MPa), standard deviations and mode of fractures distribution (\%) of glass-fiber posts luted to contaminated root canal dentin as a function of the solution employed in the decontamination process

\begin{tabular}{ccccc}
\hline $\begin{array}{c}\text { Decontamination } \\
\text { solution }\end{array}$ & $\begin{array}{c}\text { Mean } \pm \text { Standard } \\
\text { deviation }\end{array}$ & Adhesive & Cohesive & Mixed \\
\hline Water & $2.70 \pm 1.0$ & $10.0 \%$ & $16.6 \%$ & $73.3 \%$ \\
$\mathrm{NaOCl}$ & $2.67 \pm 0.7$ & $31.0 \%$ & $0.0 \%$ & $68.9 \%$ \\
$\mathrm{CHX}$ & $3.76 \pm 0.6^{*}$ & $13.3 \%$ & $30.0 \%$ & $56.7 \%$ \\
\hline
\end{tabular}

* Significant difference $(p<0.05)$ 

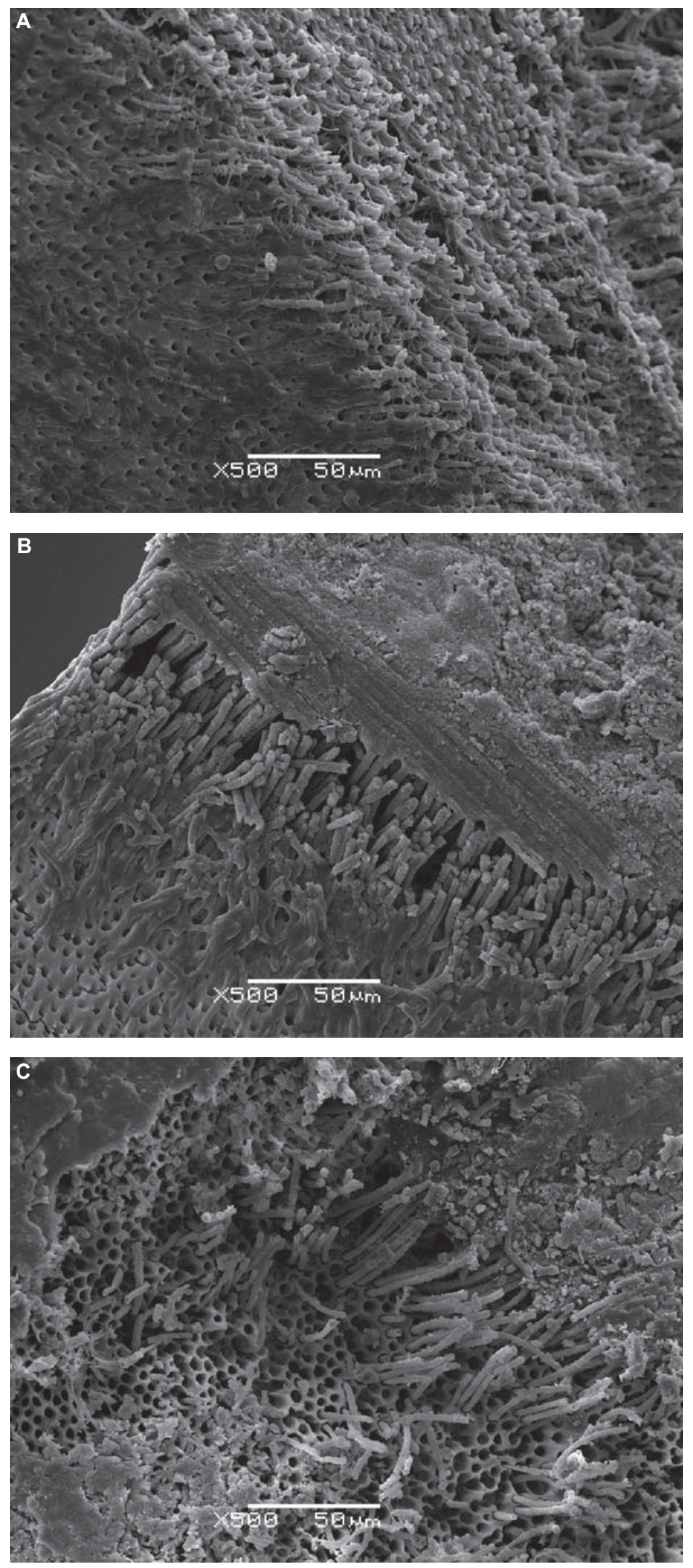

Figure 1- Representative images showing the presence of resin tags in the different groups evaluated: A) Distilled water, B) $\mathrm{NaOCl}$, and C) $\mathrm{CHX}(500 \times)$ 


\begin{tabular}{|c|c|c|}
\hline & $\mathbf{1} \mathbf{h}$ & $\mathbf{3 0}$ days \\
\hline $\begin{array}{c}\text { Control } \\
\text { (no decontamination) }\end{array}$ & $1.06 \times 1010$ & $1.2 \times 1011$ \\
\hline Water & $1.43 \times 1010$ & $1.8 \times 1011$ \\
\hline $\mathrm{NaOCl}$ & 0 & $1.74 \times 1010$ \\
\hline $\mathrm{CHX}$ & 0 & 0 \\
\hline
\end{tabular}

Figure 2- Number of CFU/ml

which is in disagreement with previous studies ${ }^{4,28}$. The short exposure time to $\mathrm{NaOCl}$ plus the action of phosphoric acid could explain these results. While increasing the application time of $\mathrm{NaOCl}$ resulted in a progressive decrease in shear-strength ${ }^{12}$, a 10-minute application results in deproteinization of collagen fibrils and compromises the adhesion process ${ }^{4}$. Therefore, the irrigation with $\mathrm{NaOCl}$ for 1 min would be insufficient to generate significant residues to significantly interfere with the bondstrength. Moreover, it has been suggested that the influence of the irrigation with $\mathrm{NaOCl}$ before the cementation of fiber-reinforced posts is adhesivedependent and may not occur with all adhesives ${ }^{8}$, which may also explain the results of the present study.

In the present study, 1-mm-thick slices obtained from removing the first $4 \mathrm{~mm}$ of the coronal region of the roots were used in the push-out evaluation. Although the evaluation of a root canal's coronal, middle, and apical thirds is common in push-out studies, it is also common to observe a regional variation, with the bond-strength decreasing from coronal to the apical region of the root canal ${ }^{2,18,29}$. For this reason, only a slice corresponding to the middle third was evaluated.

The use of sterile distilled water after $E$. faecalis exposure, far from decontaminating, increased the number of CFU/ml. This result suggests that an antimicrobial solution should be used when there is contamination during the preparation of root canals to receive posts. It is important however to note that in the teeth used to evaluate the $\mathrm{CFU} / \mathrm{ml}$, phosphoric acid was not applied as in the bond-strength evaluation. It should also be pointed out that only eight teeth were used for CFU evaluation. This further evaluation was conducted to ensure that both $\mathrm{NaOCl}$ and $\mathrm{CHX}$ were effective antibacterial solutions.

The decontamination with $\mathrm{CHX}$ was more effective than with $\mathrm{NaOCl}$, when contamination occurred for 30 days, which is in agreement with a previous study ${ }^{15}$. $\mathrm{NaOCl}$ solutions have the ability to dissolve organic matter as well as antimicrobial action, however, its penetration into the root canal dentin seems to be limited to $\approx 300$ $\mu \mathrm{m}^{13,31}$ while bacteria have been found in deeper layers of $\approx 500 \mu \mathrm{m}$ into infected dentin ${ }^{1}$. Although the present study was not designed to evaluate the decontamination of deep dentin layers, it can be hypothesized that if bacterial contamination remains in these deep layers, the long-term behavior of the treatment may be jeopardized. Moreover, it has also been shown that at low concentrations, $\mathrm{NaOCl}$ may be ineffective against E. faecalis ${ }^{7}$. Thus, the results of the present study could be different if $5 \% \mathrm{NaOCl}$ was used instead of $2.5 \% \mathrm{NaOCl}$. $\mathrm{CHX}$, on the other hand, is an antiseptic of wide antimicrobial spectrum and substantivity. The substantivity is the prolonged association between $\mathrm{CHX}$ and the dental surface, with the material remaining active on the tooth surface for prolonged periods ${ }^{23}$. This characteristic may add some advantage to $\mathrm{CHX}$ when compared to $\mathrm{NaOCl}$ solutions.

In the present study, $2 \% \mathrm{CHX}$ has increased the bond strength. This result is in agreement with another study that evaluated the influence of $\mathrm{CHX}$ on the immediate bond strength of fiber-reinforce posts to root canal dentin, and observed a slight improve in bond strength for three of the four posts evaluated ${ }^{14}$. It should be noted, however, that for coronal dentin, $2 \% \mathrm{CHX}$ do not affect immediate bond strength values in general, as compared to control groups (without the use of $\mathrm{CHX}^{16}$ ). Although $\mathrm{CHX}$ was used in the present study due to its potent antimicrobial effect, and only the immediate bond strength was evaluated, the long-term stability of the adhesive bonding to the root canal dentin could also be benefited ${ }^{27}$. Dentin debonding is currently the main problem when resin-based materials are adhesively bonded to the dental structure. This process of debonding has been shown to be related to the degradation of collagen fibrils due to the activity of enzymes such as matrix metalloproteinases (MMPs) and cysteine cathepsins ${ }^{25}$. The use of $\mathrm{CHX}$ to prevent hydrolysis of the collagen matrix at the hybrid layer is one of the approaches currently employed to improve the durability of dentin bonds ${ }^{3,25}$.

It should be noted that a steam autoclave was used in the present study. The high temperatures could have altered collagen fibrils, impairing the adhesive process. At the same time, while autoclaving may end MMPs' enzymatic activities in dentin, dentinal gelatinases have detected even after the autoclave treatment of dentin ${ }^{24}$. Although the irrigation with $\mathrm{NaOCl}$ did not influence the push-out bond-strength in the present study, the use of $\mathrm{CHX}$ seems to be more appropriate, since it showed a better decontamination property. Further studies with other adhesives and resin cements should be conducted, as the influence of $\mathrm{NaOCl}$ and $\mathrm{CHX}$ may be different with the use of other resin-based materials, since the use of $\mathrm{CHX}$ has also shown controversial results ${ }^{2}$. 


\section{CONCLUSION}

The decontamination with $\mathrm{NaOCl}$ was effective only when the contamination occurred for $1 \mathrm{~h}$, while $\mathrm{CHX}$ was effective at both contamination times. The bond-strength of the glass-fiber posts and resin cement to dentin was not negatively affected by the irrigation with $\mathrm{NaOCl}$.

\section{ACKNOWLEDGMENTS}

The authors acknowledge FGM Produtos Odontológicos, Joinville, SC, Brazil for providing the resin-based materials and glass-fiber posts employed in the present study.

\section{REFERENCES}

1- Ando N, Hoshino E. Predominant obligate anaerobes invading the deep layers of root canal dentin. Int Endod J. 1990;23(1):20-7. 2- Araújo DF, Chaves LP, Bim O Jr, Garcia FC, Ishikiriama SK, Honório $\mathrm{HM}$, et al. Influence of $2 \%$ chlorhexidine digluconate on bond strength of a glass-fibre post luted with resin or glassionomer based cement. J Dent. 2014;42(6):735-41.

3- Campos EA, Correr GM, Leonardi DP, Barato-Filho F, Gonzaga CC, Zielak JC. Chlorhexidine diminishes the loss of bond strength over time under simulated pulpal pressure and thermo-mechanical stressing. J Dent. 2009;37(2):108-14.

4- Cunha LF, Furuse AY, Mondelli RF, Mondelli J. Compromised bond strength after root dentin deproteinization reversed with ascorbic acid. J Endod. 2010;36(1):130-4.

5- Del Carpio-Perochena AE, Bramante CM, Duarte MA, Cavenago $B C$, Villas-Boas $M H$, Graeff MS, et al. Biofilm dissolution and cleaning ability of different irrigant solutions on intraorally infected dentin. J Endod. 2011;37(8):1134-8.

6- Demiryürek EO, Külünk $S$, Saraç D, Yüksel G, Bulucu B. Effect of different surface treatments on the push-out bond strength of fiber post to root canal dentin. Oral Surg Oral Med Oral Pathol Oral Radiol Endod. 2009;108(2):e74-80.

7- Dornelles-Morgental R, Guerreiro-Tanomaru JM, Faria-Júnior NB, Hungaro-Duarte MA, Kuga MC, Tanomaru-Filho M. Antibacterial efficacy of endodontic irrigating solutions and their combinations in root canals contaminated with Enterococcus faecalis. Oral Surg Oral Med Oral Pathol Oral Radiol Endod. 2011;112(3):396-400. 8- Furuse AY, Cunha LF, Baratto SP, Leonardi DP, Haragushiku GA, Gonzaga CC. Bond strength of fiber-reinforced posts to deproteinized root canal dentin. J Contemp Dent Pract. 2014;15(5):581-6.

9- Goracci C, Ferrari M. Current perspectives on post systems: a literature review. Aust Dent J. 2011;56:77-83.

10- Grecca FS, Rosa AR, Gomes MS, Parolo CF, Bemfica JR, Frasca $L C$, et al. Effect of timing and method of post space preparation on sealing ability of remaining root filling material: in vitro microbiological study. J Can Dent Assoc. 2009;75(8):583.

11- Guneser MB, Akbulut MB, Eldeniz AU. Effect of various endodontic irrigants on the push-out bond strength of biodentine and conventional root perforation repair materials. J Endod. 2013;39(3):380-4.

12- Hayashi M, Takahashi Y, Hirai M, Iwami Y, Imazato S, Ebisu $S$. Effect of endodontic irrigation on bonding of resin cement to radicular dentin. Eur J Oral Sci. 2005;113(1):70-6.
13- Kuga MC, Gouveia-Jorge E, Tanomaru-Filho M, GuerreiroTanomaru JM, Bonetti-Filho I, Faria G. Penetration into dentin of sodium hypochlorite associated with acid solutions. Oral Surg Oral Med Oral Pathol Oral Radiol Endod. 2011;112(6):e155-9.

14- Lindblad RM, Lassila LV, Salo V, Vallittu PK, Tjäderhane L. Effect of chlorhexidine on initial adhesion of fiber-reinforced post to root canal. J Dent. 2010;38(10):796-801.

15- Menezes MM, Valera MC, Jorge AO, Koga-Ito CY, Camargo $\mathrm{CH}_{\text {, }}$ Mancini MN. In vitro evaluation of the effectiveness of irrigants and intracanal medicaments on microorganisms within root canals. Int Endod J. 2004;37(5):311-9.

16- Montagner AF, Sarkis-Onofre R, Pereira-Cenci T, Cenci MS. MMP Inhibitors on dentin stability: a systematic review and metaanalysis. J Dent Res. 2014;93(8):733-43.

17- Pappen AF, Bravo M, Gonzalez-Lopez S, Gonzalez-Rodriguez MP. An in vitro study of coronal leakage after intraradicular preparation of cast-dowel space. J Prosthet Dent. 2005;94(3):2148.

18- Pereira JR, Rosa RA, Só MV, Afonso D, Kuga MC, Honório HM, et al. Push-out bond strength of fiber posts to root dentin using glass ionomer and resin modified glass ionomer cements. J Appl Oral Sci. 2014;22(5):390-6.

19- Prado M, Simão RA, Gomes BP. Effect of different irrigation protocols on resin sealer bond strength to dentin. J Endod. 2013;39(5):689-92.

20- Rasimick BJ, Wan J, Musikant BL, Deutsch AS. A review of failure modes in teeth restored with adhesively luted endodontic dowels. J Prosthodont. 2010;19(8):639-46.

21- Sagsen B, Zortuk M, Ertas H, Er O, Demirbuga S, Arslan H. In vitro fracture resistance of endodontically treated roots filled with a bonded filling material or different types of posts. J Endod. 2013;39(11):1435-7.

22- Santos-Filho PC, Veríssimo C, Soares PV, Saltarelo RC, Soares CJ, Marcondes Martins LR. Influence of ferrule, post system, and length on biomechanical behavior of endodontically treated anterior teeth. J Endod. 2014;40(1):119-23.

23- Souza M, Cecchin D, Farina AP, Leite CE, Cruz FF, Pereira CC, et al. Evaluation of chlorhexidine substantivity on human dentin: a chemical analysis. J Endod. 2012;38(9):1249-52.

24- Sulkala M, Tervahartiala T, Sorsa T, Larmas M, Salo T, Tjäderhane L. Matrix metalloproteinase-8 (MMP-8) is the major collagenase in human dentin. Arch Oral Biol. 2007;52(2):121-7. 25- Tjäderhane L, Nascimento FD, Breschi L, Mazzoni A, Tersariol $\mathrm{IL}$, Geraldeli S, et al. Optimizing dentin bond durability: control of collagen degradation by matrix metalloproteinases and cysteine cathepsins. Dent Mater. 2013;29(1):116-35.

26- Tjäderhane L, Nascimento FD, Breschi L, Mazzoni A, Tersariol $\mathrm{IL}$, Geraldeli S, et al. Strategies to prevent hydrolytic degradation of the hybrid layer - a review. Dent Mater. 2013;29(10):999-1011. 27- Toman M, Toksavul S, Tamaç E, Sarikanat M, Karagözoğlu I. Effect of chlorhexidine on bond strength between glass-fiber post and root canal dentine after six month of water storage. Eur J Prosthodont Restor Dent. 2014;22(1):29-34.

28- Vongphan N, Senawongse P, Somsiri W, Harnirattisai C. Effects of sodium ascorbate on microtensile bond strength of total-etching adhesive system to $\mathrm{NaOCl}$ treated dentine. J Dent. 2005;33(8):689-95.

29- Wang VJ, Chen YM, Yip KH, Smales RJ, Meng QF, Chen L. Effect of two fiber post types and two luting cement systems on regional post retention using the push-out test. Dent Mater. 2008;24(3):372-7.

30- Zehnder M. Root canal irrigants. J Endod. 2006;32(5):389-98. 31- Zou L, Shen Y, Li W, Haapasalo M. Penetration of sodium hypochlorite into dentin. J Endod. 2010;36(5):793-6. 